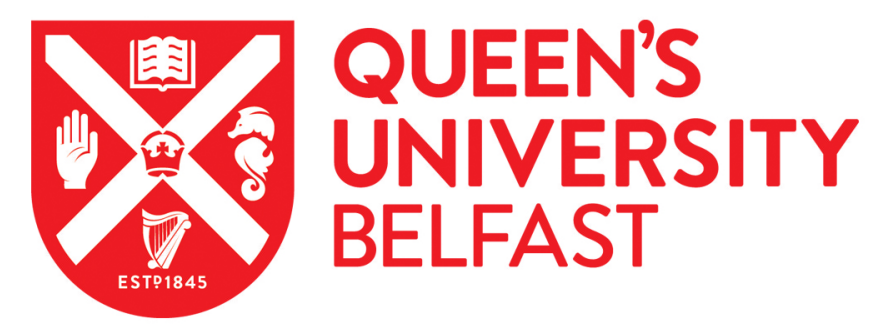

\title{
To settle for a gendered peace? Spaces for feminist grassroots mobilization in Northern Ireland and Bosnia-Herzegovina
}

Deiana, M-A. (2016). To settle for a gendered peace? Spaces for feminist grassroots mobilization in Northern Ireland and Bosnia-Herzegovina. Citizenship Studies, 20(1), 99-114.

https://doi.org/10.1080/13621025.2015.1054790

\section{Published in:}

Citizenship Studies

\section{Document Version:}

Peer reviewed version

Queen's University Belfast - Research Portal:

Link to publication record in Queen's University Belfast Research Portal

Publisher rights

(c) 2015 Taylor \& Francis.

This work is made available online in accordance with the publisher's policies. Please refer to any applicable terms of use of the publisher.

\section{General rights}

Copyright for the publications made accessible via the Queen's University Belfast Research Portal is retained by the author(s) and / or other copyright owners and it is a condition of accessing these publications that users recognise and abide by the legal requirements associated with these rights.

Take down policy

The Research Portal is Queen's institutional repository that provides access to Queen's research output. Every effort has been made to ensure that content in the Research Portal does not infringe any person's rights, or applicable UK laws. If you discover content in the Research Portal that you believe breaches copyright or violates any law, please contact openaccess@qub.ac.uk. 
Accepted Manuscript Citizenship Studies, 20 (1), pp.99-114.

Title: To Settle for a Gendered Peace? Spaces for feminist grassroots mobilization in Northern Ireland and Bosnia-Herzegovina.

Author: Maria-Adriana Deiana

Affiliation: School of History, Anthropology, Politics, and Philosophy, Queen's University Belfast

Telephone number: +447480116390

Email: m.deiana@qub.ac.uk

To Settle for a Gendered Peace?

Spaces for feminist grassroots mobilization in Northern Ireland and Bosnia-

Herzegovina.

\begin{abstract}
This paper offers an examination of citizenship in the context of post-conflict transformation as an important scenario in which to investigate the possibilities for the inclusion of women and women's demands in the transition to peace. Drawing on interview and ethnographic data collected in Northern Ireland and Bosnia-Herzegovina the paper highlights a site of tension between the aspirations for transformation and inclusion set out internationally in UNSCR1325 and the gender underpinnings of consociationalism that shape the broader political, social and cultural context of citizenship in these case-studies. It illustrates that women and women's claims are repeatedly side-lined in favour of matters which are deemed of more vital interest in the quest for "peace", such as relations between ethnonational groups, security concerns and stability of institutions. Despite this damning failure, women and feminist activists continue to mobilise, as individuals and collectively, in order to make demands for social, political and cultural transformation. The paper argues that attending to these dynamics is crucial if we strive to transform the gender regimes underpinning war/peace and acknowledge women as agents in this process.
\end{abstract}

Key words: UNSCR1325; consociationalism; gender, conflict; feminist activism; 


\section{Introduction}

In the last fifteen years, academic engagements with the gendered implications of conflict and post-conflict transformation have mainly revolved around the signing of UN Security Council Resolution 1325 (hereafter UNSCR1325). Welcomed as a landmark document, UNSCR1325 is both regarded as a significant moment for women's and peace activism, as well as the focus of intense critical scrutiny. ${ }^{i}$ I take the cue from recent debates that gesture towards the need to critically interrogate UNSCR1325 in terms of its applicability to widely different conflict and post-conflict scenarios and in relation to its relevance to women's activism and everyday life in these contexts (Farr, 2011; McLeod, 2011). I am particularly interested in engaging with the tensions between the Resolution's commitment to highlighting the significance of women's agency and inclusion in peace and security, and the structural factors that may constrain women's agency and perpetrate gendered exclusions (Pratt and Richter-Devroe, 2011, Shepherd, 2011).

This paper brings to the fore two post-conflict contexts -Bosnia-Herzegovina $(\mathrm{BiH})$ and Northern Ireland (NI) - that add complexity to this tension. It does so by highlighting how institutionalised approaches to peacebuilding that rely on consociationalism, such as those deployed in the two case-studies under examination, produce and reiterate profound gender exclusions that in many ways contradict the visions and principles ratified in UNSCR1325. I argue that by entrenching ethnonationalism as dominant political discourse, consociational agreements inevitably work to sideline gender dynamics of conflict and conflict transformation, hence producing peace settlements that are not only explicitly ethnicised but also implicitly gendered. If we strive to critically interrogate the Resolution's transformative potential, this contradiction (or at least friction) between consociationalism and the spirit of UNSCR1325 must be taken seriously. At the same time I contend that this analytical effort needs further supplementation. My objective is to demonstrate that both post-conflict scenarios present dynamics outside the strictly institutional dimension that work to continuously relegate gender concerns and women's experiences to the margins of the political agenda. Despite such constraints, however, feminist activists and women continue to mobilise, as individuals and collectively, to make demands for social, political and cultural transformation.

In order to capture the interplay between these dynamics I move away from offering an analysis of UNSCR1325 implementation in the case-studies under consideration. Rather I argue that the notion of citizenship can provide an alternative entryway to examine the possibilities for the inclusion of women and women's demands in processes of post-conflict transformation. ${ }^{\text {ii }}$ More specifically, I draw on feminist reformulations of citizenship to develop a critical analysis of the outworkings of consociationalism, and examine the interaction between persisting constraints and the efforts of women "on the ground" to re-imagine citizenship. 
This is only possible if we consider citizenship as multidimensional (Roseneil, 2013) and multilayered (Yuval-Davis, 1999). Citizenship here is conceptualised beyond its formal dimension of institutionalised practices and discourses. It entails both a sense of (often overlapping and multiple) belongings and a set of lived practices that are constantly reconfigured by broader social and cultural dynamics. I am particularly drawn to feminist reformulations that place an emphasis on women's agency in a variety of locales and hence attend to the "bottom-up", agentic nature of women's mobilization (Lister, 2007; Halsaa, Roseneil, and Sümer, 2012). Remaking citizenship for women entails demands for political voice, civil and social rights, and opportunities for engagement in multiple sites.Within this perspective citizenship is also enacted through a demand for expanding what constitutes the "political", for instance through creating new spaces and strategies for mobilization. Crucially this pluralist and participatory understanding challenges the exclusionary connotation of ethnonational citizenship that, as I will discuss shortly, places an emphasis on women's active and passive role within the confines of the nationalist project, community and belonging,

In this paper "gender" and "women" are not used interchangeably, rather I follow a longestablished feminist trajectory of starting from the perspective of women's everyday life (Enloe, 2000) in order to interrogate the notion of citizenship, illuminate its gendered exclusions as well as its contestation . I also acknowledge the inherently problematic nature of the term "women" as an allencompassing category. Rather, I deploy it as an umbrella term that refers to (self-identifying) women as diversely positioned individuals. In doing so, I keep a critical eye on the intersections between race, class, gender, sexuality, ethnicity as they are constantly negotiated, and to the complex ways in which the legacy of ethno-national conflict and identity politics might exacerbate these differentials. To be clear, I am not suggesting that ethno-national divisions can be overcome once and for all, nor I am attempting to downplay the relevance that ethnicity/national(ist) belonging might also have for (some) women's practices of citizenship. Rather I am interested in attending to those moments where women's experiences/voices take centre-stage in the claims, demands, discursive and cultural practices enacted by feminists and women activists, while ethno-national belonging, differences along ethnic fault lines and diverging views on the legacy of conflict might, even momentarily, become less relevant.

Drawing on interview and ethnographic data ${ }^{\mathrm{iii}}$ this paper asks: What do we learn from the experiences of women in Northern Ireland and Bosnia-Herzegovina about the intersection between gender, citizenship and consociationalism in the context of post-conflict transformation? What kind of insights can these offer to broader discussions about the relevance and applicability of UNSCR1325 to different conflict scenarios and women's experiences? The next section discusses the rationale for bringing the two case-studies together. I then develop a feminist critique of consociationalism by illustrating the gendered nature of the respective peace settlements and the implications this holds for women's citizenship claims and experiences. Finally I discuss the critical and generative potential of women's 
and feminist sustained activism in challenging "post-conflict/post-agreement" exclusions and reimagining citizenship for women.

\section{Peace Talks ....and Silences: A Rationale for Comparison}

Looking at the two case-studies comparatively does not assume a level playing field between the complex and diverse historical contexts of political violence and conflict in Northern Ireland and Bosnia-Herzegovina. Rather, I aim to illustrate specific dynamics in order to critically investigate the promises and premises of the so called "peace". Despite context-specific differences, the cases under examination present some striking similarities. The respective peace processes are at a similarly advanced stage with BiH's Dayton Peace Agreement (1995) and NI's Good Friday Agreement (1998) ratified only a few years apart. Both peace settlements rely on a consociational framework. As many have argued, a key weakness of consociationalism lies in the fact that, by reinforcing the ethnic basis of politics, it produces a notion of citizenship which is mainly understood in ethnic terms (Raccioppi \& O'Sullivan, 2006; Guzina, 2007). Evidence from both cases indicates that this has exclusionary implications that go beyond the institutional framework, shaping the broader context that defines citizens' belonging and participation. As I will argue, the exclusionary enactments of consociational settlements must be further problematized by taking gender as an analytical category.

Reached through US-led politico-military negotiations among international officials and nationalist leaders, the Dayton Peace Agreement (DPA) established a post-conflict political settlement and shared institutions for Bosnia-Herzegovina. Drafted as key part of the agreement, the constitutional law enshrines ethnonationalism as dominant discourse by encouraging, and in some instances requiring, citizens to identify themselves as either Bosniaks, Croats, Serbs or "The Others", a category officially designed to identify ethnic minorities. As Sarajlić notes the constitutional framework favours the dominant but marginalizes minority ethnic and other groups, and has been deemed incompatible with anti-discrimination law by the European Court of Human Rights (2012:376). These exclusionary enactments are visible in the broader political, social, cultural context. For instance, citizens' identity and participation remains largely circumscribed by ethnic allegiances, a result of war-time population shifts now reflected in BiH's two entities, the Federation (predominantly Bosniak and Croat) and Republika Srpksa (predominantly Serb) . Ethnicity is visible in many aspects of political life such as housing segregation and voting, as well as culture, written and spoken language and education. Further to this, the agreement has worked to preserve ethno-national discourses within the politics of $\mathrm{BiH}$. It reinforces a highly divisive political life whereby dominant nationalist parties continue to mobilize the legacy of conflict and the negative constructions of "the Ethnic Other" in order to ensure support for nationalist politics (Deiana, 2013a).

In Northern Ireland, the Good Friday Agreement was also the outcome of complex negotiations aimed at ending the three decades of political conflict between the two dominant ethno-national 
communities. The implementation stage saw the entrenchment of ethno-national politics become more prominent with the increasing electoral ascendency of the Democratic Unionist Party and Sinn Féin the parties associated respectively with 'militant' unionism and nationalism (Wilford, 2010). ${ }^{\text {iv }}$ Moments of political deadlock have led to the suspension of the devolved institutions. In 2006, a new round of elite-bargaining negotiations culminated in the St. Andrews Agreement, which strengthened the electoral dominance of the DUP and SF and, as a result, continue to reinforce the primacy of ethnonationalist affiliations in the democratic structures, as well as in the broader political discourse. For instance, segregation and distrust are particularly evident in/near interface areas between the "two communities" and entrenched by separated schooling based on religious affiliation (Huges, 2011). The legacy of conflict remains highly divisive and contested. With voting occurring mainly along ethnonationalist fault lines and little agreement on strategies in order to deal with the past, exclusionary politics continues to be the political discourses pursued by dominant parties.

Developed as political responses to the imperative of finding a "stable" solution to conflict, peace settlements in both contexts have been "successful" in reducing violence and establishing shared institutions. However these solutions also entailed a trade-off whereby the peace-process has led to the entrenchment of ethno-nationalism in the broader social and cultural discourse underpinning citizenship.I argue that this trade-off engenders a further unexpected outcome whereby consociational solutions produce a notion of citizenship which is not only explicitly ethnicised but also implicitly gendered. More recently, moments of political deadlock and unrest beset the stability of the peace processes leading to further rounds of consultations. In $\mathrm{BiH}$, a series of public protests began in the summer 2013 calling for the government's accountability on a number of issues and inevitably brought attention to the (unresolved) issue of constitutional reform. ${ }^{\mathrm{v}}$ Under the auspices of the EU delegation and the High Representative, a new series of peace talks involving the nationalist parties' leaders took place in autumn 2013. Civil society groups saw the talks as an opportunity for mobilization, including a number of local women's NGOs and individual activists who advocated for the inclusion of gender discrimination among the issues to be negotiated for constitutional reform and called for a more transparent and participatory process as "the basis for establishing a truly functional and democratic society" (WILPF International, 2013). In NI, the political situation deteriorated in December 2012 with episodes of unrest and rioting resulting from a dispute over the Belfast City Council vote to limit the number of days the Union flag is flown on City Hall, which raised concerns in some loyalist communities. In response to months of unrest the Northern Ireland Executive invited Richard Haass and Megan O'Sullivan to undertake a series of consultations on three contested issues - flags, parades and dealing with the past- that highlight key challenges to the peacebuilding process. In a similar vein to the Bosnian women's NGOs, a network of local women's groups seized the opportunity to engage in the talks by submitting a report on the experiences of women living through the conflict and the subsequent period of peacebuilding (Carvill, 2014). After months of negotiations, the talks failed to 
reach an agreement. The final report produced by the Haass-O'Sullivan team contained no specific reference to women's role and perspectives.

Nearly two decades after the original peace negotiations and fourteen years after the ratification of 1325 the latest rounds of peace talks in Northern Ireland and Bosnia-Herzegovina demonstrate that women's perspectives in devising future strategies of conflict transformation continue to be marginalised and excluded. I argue that this outcome is, however, far from surprising as the two political scenarios illustrate generalised and context-specific dynamics that highlight an evident disjunction between official discourses and political processes, and the efforts of feminist activists and women's groups to make their voices and perspectives visible in the respective peacebuilding projects.

\section{Post-Dayton and Post-Good Friday: Settlements for a Gendered Peace.}

One unanticipated outcome of consociationalism lies in the fact that, by entrenching ethnonationalism as key political discourse it also inevitably reproduces elements of its gender order and fails to address gender as a salient category in the interrelated phenomena of ethno-nationalism and armed conflict. Byrne and McCulloch (2012) have also highlighted this problem by examining the tensions between power-sharing/consociational institutions and women's political representation in post-conflict scenarios $^{\mathrm{vi}}$. This article builds on but ultimately diverges from their work in that it frames the analysis beyond the strictly institutional dimension and examines the broader implications that consociationalism holds for women's citizenship. Here I argue that, in establishing a continuity between nationalist rhetoric, the phase of conflict and the transition to "relative" peace, consociational settlements produce an exclusionary notion of citizenship which is not only ethnicised, but also implicitly gendered with important implications for women's lived experiences, agency and inclusion.

Within ethno-national narratives citizenship becomes associated with notions of national essence and powerful constructions of ethnic and national identities, which rely on specific ideas of femininity and masculinity (e.g. Enloe; 1989, Kandiyoti, 1996, Yuval-Davis, 1997). The discursive context underpinning the emergence of nationalist politics in the former Yugoslavia and the explosion of the Bosnian war clearly illustrate these gender dynamics. Women were depicted as victims, symbols and mothers of the Nation(s), becoming markers of national honour and identity (Milić, 1993). Heroic metaphors, such as guardians, warriors and saviours of the nation, produced manliness and virility as the canon for the "proper" male citizen (Mostov, 1999). Images of the nation as a woman were prominent in the media, the trope of "the motherland" was often evoked in political speeches and more generally in the nationalist iconography (Žarcov, 2007). On the other hand, feminists, women activist and anti-nationalists were depicted as national traitors, trouble-makers and witches, a derogatory term infamously employed in 1992 by nationalists against Croatian feminists who dared to question the national cause and still used today to attack and discredit outspoken women and feminists (Kesić, 1999). The conflict signalled a dramatic shift whereby from markers of collective identity women 
became physical targets of violence. However, women also had a more active role in response to nationalism and in the war. Women's and feminist activism in the region played a crucial role in opposition to the very nationalist logics which cast them as victims and passive subjects. Women's political agency in the immediate aftermath of the Bosnian war occurred mainly through the creation of informal groups, initially to deal with the humanitarian emergency arising from the conflict (Walsh, 2001). However this mobilization can be traced back to the anti-war demonstrations in the wake of Yugoslavia's violent break-up in Serbia, Croatia, Slovenia and Bosnia which involved the first generation of Yugoslav feminists together with younger women, students, mothers of soldiers and, later, refugees (e.g. Slapšak, 1997, Helms, 2003, Dević, 2010). The highly divisive and violent context of the war led to divisions among some women's groups along ethnic fault lines but crucially a good number of women's and feminist organisations remained in opposition to ethno-nationalist rhetoric across the region, found ways to cooperate across the ethnic divide and contribute to women's peace and security effort (Mladjenovic and Huges, 1999; Korac, 2003).

Despite these complex dynamics, the peace negotiations did not include gender as key dimension for addressing the legacy of conflict and building sustainable peace. The final document failed to address the varied impact of conflict on men and women and ensure women's participation in the peace process (Chinkin and Paradine, 2001). Despite reference to key human rights documents such as the Convention on the Elimination of Discrimination Against Women (CEDAW), it did not envision strategies for the inclusion of women in key institutions. No specific measures were included to address the clearly gendered legacy of conflict, such as conflict -related sexual violence and other forms of gender based violence, vulnerability to exploitation and social stigma for women refugees and displaced persons, gender discrimination in the right to return and to property and in the access to social welfare. Finally the agreement gave a low imperative to the role of civil society in ensuring sustainable peace and overlooked women's active involvement in anti-nationalist protests and humanitarian activism, in some cases also across the ethnic divide (Kivinna til Kvinna, 2000).

Attempts to address DPA's gender shortcomings resulted in the creation of a multi-level institutional gender mechanism, a Law on Gender Equality by the BiH parliament (2003) and a national Gender Action Plan, (2006) (Žene Ženama, 2007). In 2010, the government of BiH adopted a National Action Plan for the implementation of UNSCR1325. However, although on legal and constitutional levels gender equality is well regulated, broader changes outside the strictly legal domain are difficult to achieve. These challenges are exacerbated by the entrenchment of ethno-nationalism and the complex legacy of conflict which remains politicised and contested. For instance, successive governments have failed to appropriately address important issues which are a direct legacy of war, such as the status of survivors of war-time sexual violence (Amnesty International, 2009). Besides highlighting an issue of human rights violation, this indicates an inconsistency between the rhetorical commitment to the NAP 
(which includes issues of conflict-related sexual violence) and the gaps in the legislation on the status of war-time rape survivors.

Outside the institutional domain, gender stereotypes fostered by ethno-nationalist politics persist, as nationalist parties continue to pursue different strategies and policies that relegate women's role to motherhood and that narrowly define the acceptable parameters of women's behaviour (Deiana, 2013a). Evidence suggests that strong social pressure is in place to silence and publicly discredit women and feminists who dare to openly critique the correlations between the current status-quo, the nationalist grip on power and the gender inequalities underlying nationalist politics (Deiana, 2013a). Outspoken women, anti-nationalist activists, journalists and feminists in particular continue to be overtly referred as trouble-makers, traitors and "witches", a misogynistic term often used to discredit women who dare to challenge ethno-nationalist power. Official discourses and institutional mechanisms express the government's commitment to increase women's participation in all levels of decision-making. At the same time, political elites continue to rely on the control of women's behaviour and the discursive manipulation of stereotypical gender roles in order to ensure support for their nationalist agenda.

Similar gender dynamics are visible in the context of Northern Ireland where, historically, definitions of womanhood have been entangled with conflicting religious and national identities and reflected the broader communal divisions in Northern Irish society. Within the Catholic/nationalist tradition, the image of the suffering Virgin Mary or the Celtic mythological symbol of the nation as the loving Mother Ireland were prominent (Hill \& White, 2012). Women combatants and revolutionaries were also central to nationalist iconography, for instance in political murals, and in political rhetoric that aimed at placing women (passively and actively) at the centre of the nationalist project (Galligan $\&$ Knight, 2011). By contrast, unionist discourses relied on women as homemakers and relegated their role in the political sphere to that of supporting male individuals. References to biblical women who embody the virtues of good mother and wife are also prominent, as well as the secular figure of the Queen (Sawyer, 1993). This iconography is visible in a few political murals and also emerges in political statements. Despite some differences, religious teaching on both sides reinforced male dominated power relations within the family and promoted a strict moral and sexual code with important implications for women's reproductive rights (Galligan \& Knight, 2011).

As in the case of $\mathrm{BiH}$, despite the limitations imposed by conservative ethno-nationalist parameters women also had a more active role during the decades of conflict. Some were actively involved in protests, marches and more overt forms of political activism. Others explicitly engaged in the conflict as combatants in republican/nationalist paramilitary groups, and through supportive/ less visible roles in loyalist groups (Alison, 2009, Potter 2014). Some women were involved in community groups and grass-roots organisations that emerged predominantly in working-class areas as a response to the deficiencies of direct-rule government in dealing with the social and economic needs of 
communities fractured by conflict and deprivation (Ward, 2005). In some instances this kind of supporting networks would also extend across the ethnic divide. Civic activism provided a crucial platform for women's active engagement, although conflicting views on the constitutional issues and on the identification with feminism remained (McWilliams, 1995). The prospect of a peace-settlement however paved the way for a more cohesive and collective, albeit short-termed, mobilization.

In contrast with the case of Bosnia-Herzegovina, women were unusually visible during the negotiations for the Good Friday Agreement, most notably through the involvement of the (crosscommunity) Northern Ireland Women's Coalition's elected representatives, Monica McWilliams and Pearl Sagar. A key achievement of the Women's Coalition was the inclusion of a separate clause on the Agreement affirming the right of full and equal political participation for women. The clause, however, remained peripheral in the implementation of the Agreement which, despite its inclusive aspirations, ultimately failed to address the centrality of gender. The document did not contain any specific measure to address the varied impact of conflict in women's lives, such as the unequal economic and social hardship experienced by women in working class and rural areas; women's safety and gender based violence in relation to "new" forms of paramilitary activity and sectarianism; long-term effects of violence on health and well-being, and increasing caring responsibilities for women as a direct result of the conflict- for example in cases where family members were injured (WRDA, 2008; Gray \& O’Neill, 2011). Crucially, it did not acknowledge women's prominent role in building the communitybased and voluntary sector and, thus, envision any specific measures to sustain women's civic activism and active engagement in public life.

Besides context-specific dynamics, both "post-conflict" scenarios have also seen a set-back in women's visibility and inclusion. For instance in NI, the changes ratified with the St. Andrew's agreement pushed gender equality further back into the political agenda and, compared to the peace negotiations, the implementation stage saw a setback on those gain. Similarly, interviewees from $\mathrm{BiH}$ argue that the "peace" has entailed a backlash in terms of women's visibility, representation and positioning in the public sphere as the men, who were predominantly involved in the military during the conflict, have resumed "normal", civilian life and/or took on new roles, such as "peacebuilders" or NGO leaders (Deiana, 2011).

In both contexts, the sustainability of women's groups and, more generally, spaces for women's civic activism is under question as international funding streams begin to phase out and national resources remain limited. The dire state of national economy and Bosnia's loss of importance in the international arena result in women's groups often competing against each other in order to access limited funding (Deiana, 2011). In Northern Ireland the climate of austerity and welfare reforms, and the uncertainties about the budget allocation for the latest Peace IV funds paradigm present similar challenges to the voluntary and women's sector. In contexts of divisive nature of ethno-national politics 
such as $\mathrm{NI}$ and $\mathrm{BiH}$, the competitive allocation of funds inevitably hinders instances of cooperation, as well as affecting the very sustainability of women's organisations.

An analysis of the peace settlements and their respective implementation illustrate a damning failure in addressing the gendered legacy of conflict and, thus, in remaking citizenship for women in the transition to the so called "peace". The rhetorical commitment to gender equality might have brought some changes in the institutional framework and made "gender concerns" visible at different stages of the respective peace processes. However, the peace process has also entailed the entrenchment of conservative ethnonational discourses in the broader social, cultural and political discourse that shapes practices of citizenship, as well as a betrayal of those (feminist) hopes for political transformation that both peacebuilding projects entailed.

The verdict of, at best, a "complex and incomplete peace" (WRDA, 2008:51) rings true for both Northern Ireland and Bosnia-Herzegovina where women and women's claims are often side-lined in favour of matters which are deemed of more immediate interest, such as "community relations" and vital group interests, security concerns and stability. The question arises, then, as to whether a gendered notion of citizenship is a necessary trade-off in the quest for peace, and more importantly whether women in Northern Ireland and Bosnia-Herzegovina have relinquished their demands, contestations and hopes?

\section{"Alternative" spaces of citizenship: between continuities and new openings.}

Against all odds women in Northern Ireland and Bosnia-Herzegovina continue to make demands for political voice, civil and social rights through collective mobilization and as individuals acting in different locales. In both case-studies it is possible to trace elements of continuity between women's mobilization during the phase of conflict and in the so called peace, as well as the emergence of new feminist formations that employ different strategies for activism. The context-specific history of women's mobilization also respectively shapes and influences women's and feminist activism today.

As stated, in Northern Ireland women's diversified platform of civic activism developed during the conflict as a form of "situated politics of everyday life" (Porter, 1998) that was -and still is - crucial for providing supporting networks in communities fractured by conflict. Despite scarce funding, women's centres in Belfast's working class areas and groups across Northern Ireland continue to offer safe spaces for women in areas still affected by the entrenchment of male-networks of power, paramilitary activities and high-levels of violence. These are important efforts to develop an alternative space for women that troubles, even momentarily, the masculinised order within their respective ethnonational communities. However, because of a specific focus at the community level, these practices do not always extend beyond the confines of ethno-national belonging. 
There are moments in which women's groups of different community affiliation mobilise collectively in a more explicitly political sense. The response to the peace talks discussed earlier is a case in point. Resulting from a series of consultations that explored the relevance of UNSCR1325 for women across the island of Ireland and the development of strategies to operationalise its potential from "the bottom up", the process engendered a space where women's collective (yet diverse) experiences took centre-stage notwithstanding divisions. ${ }^{\text {vii }}$ Not only do these interventions draw attention to the gendered shortcoming of the peace process, but they entail a critical potential as they manage to momentarily permeate the boundaries of the ethnicised order to make collective demands for women's inclusion and participation.

Similar efforts also take place outside the institutionalised domain and the formal women's and NGO sector through newly founded grassroots groups such as the collective Reclaim the Agenda and Belfast Feminist Network (BFN). ${ }^{\text {viii }}$ Both groups have an explicit political agenda that revolves around feminist collective mobilization and a broad membership that extends beyond ethno-national affiliations. Since its inception, Reclaim the Agenda has worked to challenge the set-backs on women's economic and personal security, the shrinking resources and spaces for women and feminist activism and, generally the false promise of prosperity brought about by the so-called peace (O'Dowd, 2014). The collective's role in re-imaging citizenship for women is crucial: it maintains close links among different generations of feminists and women activists, bringing together more formal organisations such as trade unions, women's centres and community groups across the political spectrum through a firm focus on reclaiming a place, a voice and a feminist agenda in contemporary Northern Ireland.

BFN brings together a younger generation of feminists. The idea of the group as a network aims to be inclusive of women and men from a variety of backgrounds and life experiences. BFN operates through social media that provides an online platform for discussion on a wide range of issues related to local politics and feminism more broadly. A core group of BFN members organises different activities with the aim to link "on-line" and "on-the ground" activism on issues as diverse as women's political participation, gender-based violence and rape culture, and the lack of reproductive rights. The combination of an explicit feminist agenda, a conscious effort to be inclusive of different perspectives and belonging, and the use of social media allows for broader membership that extends beyond traditional forms of community-based activism. BFN is a younger and "technological" feminist community rooted in the feminist challenges and broader pockets of civic activism emerging in the specific context of "post-conflict/post-Agreement" NI. By bringing feminist politics to the fore of activism, BFN also challenges the exclusive focus on ethno-national belonging as the one and only dimension of citizenship in Northern Ireland.

In the case of Bosnia, the history of women's and feminist movements was by and large characterised by an anti-war and anti-nationalist stance that began with the cross-ethnic mobilisation 
against the rise of nationalist parties and continued throughout the war. Maja Korac provides a poignant description of women's agency as a "politics of small steps" (Korac, 2006:516) which captures the informal and non-institutionalised character of women's groups, and aptly describes a kind of activism born out of the "exceptional" situation of the war. In the implementation stages of the DPA the number of women's organisations grew exponentially, as well as their remit, ranging from service providing/humanitarian activities to more explicitly political activism. Despite scarce resources and the limitations of project-lead international funding paradigms, organisations such as Medica in Zenica and Udružene Žene in Banja Luka continue to provide key services in order to address the legacy of wartime sexual violence, and gender- based violence more generally, while groups like Žene Ženama in Sarajevo have established a political profile through their lobbying and consultancy activities. These are important interventions that strive to create an alternative space for women's citizenship claims and thus challenge the masculinist order of citizenship and the gendered legacy of war. However, some interviewees suggests that the Dayton divisive administrative structure and the entrenchment of ethnonational politics often hinders the development of a collective and more explicit critique of the ethnicbased notion of citizenship. At the same time, as in the case of Northern Ireland, there are moments in which women's organisations can build strategic allegiances and mobilise collectively across BosniaHerzegovina. Interesting examples include the campaign for the creation of the Law on Gender Equality (2003), the establishment of a cross-entity network to address gender -based violence and, as discussed earlier, the collective response to the latest round of peace negotiations that draw specifically on the 1325 commitments.

Examples of feminist collective mobilization can be identified among a younger, community of activists that has emerged in Sarajevo. The cultural organisation CRVENA (RED) and Cure (Girls), a feminist NGO, are a case in point that, in a similar vein to the Belfast Feminist Network, work at the intersection of "online" and "on-the-ground" activism. ${ }^{\text {ix }}$ Both groups are rooted within the challenges and opportunities for activism in "Post-Dayton" BiH and engage with broader discussions and actions within transnational feminism. CRVENA's key strategy focuses on the employment of feminist art and cultural interventions in the public space to raise questions such as the positioning of women in everyday life, politics and society, in the shift between socialism and capitalism, in the public/private divide. As stated by interviewees, this is a conscious decision that aims at circumventing the allencompassing focus on ethnic divisions in the dominant political discourses. Cure's activities also stem from members' interests and experiences, including projects such as Pitchwise, a festival of women's art, music and culture, Herstory an archive documenting the women's movement in BosniaHerzegovina, and other itinerant workshops across $\mathrm{BiH}$. In keeping with the history of feminist mobilization in the Former Yugoslavia, Cure gathers a group of young women alongside more "senior" members with a long-standing involvement in the BiH women's sector and broadly in the Yugoslav feminist movement. CRVENA's activists are also involved in trans-regional/cross-national activities 
that aim to collect and acknowledge the work of women artists, activists and scholars from the postYugoslav region. The cooperation of feminists from Sarajevo, Belgrade, Ljubljana and Zagreb remains a particularly important legacy that continues to challenge the divisive nature of ethnonationalist politics and promotes alternative modes of civic engagement by bringing feminist politics to the fore of citizenship practices in the region.

In both case-studies this diverse series of feminist interventions certainly encapsulate an attempt to create alternative spaces of grassroots mobilization. Younger activists might draw on new strategies, such as the power of social media and creative cultural interventions which are shaped by personal experiences of "growing up" and living in time of "peace", inasmuch as instances of "frontline feminism" (Cockburn, 2013) and "politics of small steps" (Korac, 2006) are expressions of activism born out of the exceptional circumstances of conflict. However, what is strikingly similar among the array of diverse experiences is the resilience of gendered exclusions that, in both case studies, have been reproduced or appeared anew in the shift from conflict to "peace".

\section{Conclusion.}

As UNSCR1325 approaches its fifteenth anniversary, research on the gendered implications of conflict and conflict transformation must field questions about the resolution's applicability to widely different scenarios, its relevance for women's experiences and the possibilities for fulfilling its transformative potential. The cases of Northern Ireland and Bosnia-Herzegovina bring into sharp focus a tension between the aspirations for participation and inclusions set out in UNSCR1325 and the gender underpinnings of consociationalism, a solution which is often held as the most viable approach to resolve ethno-nationalist disputes and armed conflict. I have argued that while consociationalism might be successful in creating shared institutions and mitigating violence, this comes at the price of marginalising gender concerns in favour of ethnicity as all-encompassing dimension of citizens' identity and belonging.

While set-backs and resistance to the implementation of gender equality mechanisms are experienced everywhere, the divisive nature of ethno-national politics inevitably takes centre stage in "post-conflict" consociational settings, where gender concerns are relegated to the margins of dominant political agenda and held hostage of a de facto "ethno-national straightjacket". In both case-studies a rhetorical commitment to gender equality has brought some changes in the institutional framework and made "gender concerns" visible at different stages of the respective peace processes. However, the transition to "peace" has also entailed a number of trade-offs and a reversal of certain fragile gains that were once achieved: women's claims are repeatedly side-lined in favour of matters which are deemed of more vital interest in the quest for "peace", such as relations between ethno-national groups, security concerns and stability of institutions. 
Despite persisting constraints, women and feminist groups continue to mobilise, as individuals and collectively, in single identity groups and across the boundaries of ethnic communities, infinitely demanding inclusion, equality and spaces of citizenship. They do so through variously effective strategies that stem from personal experiences, reflect different positioning in the specific social, political and cultural contexts of Northern Ireland and Bosnia-Herzegovina, as well as engagement with other women's and feminist movements transnationally. I have suggested that there is a critical potential in those moments when women's experiences/voices take centre-stage in the claims, demands, discursive and cultural practices enacted collectively. This is particularly true for feminist interventions that, by bringing gender concerns to the fore of the "political" and exposing the making of a complex and incomplete peace, also momentarily trouble the all-encompassing focus on ethno-national politics in citizenship institutionalised practices and discourses.

I suggest that the evidence from Northern Ireland and Bosnia-Herzegovina might be instructive for the ongoing critical reflection on UNSCR1325 in a number of ways. I have argued that we must look beyond the strictly institutional dimension and capture the broader dynamics shaping women's experiences of post-conflict transformation and the possibilities for women's agency. In the contexts under examination, this entails attending in seriousness to the tensions between the aspirations set out in UNSCR1325 and the outworkings of consociationalism that shape the broader political, social and cultural context of citizenship. We should also pay attention to the resilience of gendered exclusions as these are either reproduced or emerge anew at different stages of a peace process notwithstanding a rhetorical commitment to gender equality mechanisms. For instance, the recent rounds of peace talks in both Northern Ireland and Bosnia-Herzegovina where once again stability and ethno-national interests took centre stage are emblematic: gender continues to be side-lined in favour of issues that are deemed a priority in post-conflict transformation, rather than being included as a crucial analytical category to be addressed in all aspects and stages of a peace process. Last but not least, I contend that UNSCR1325 might be an excellent tool for political manoeuvring, however in order to be effective it needs continuous supplementation from women's lived experiences of conflict and post-conflict transformation. This includes attending to instances of feminist activism that might not necessarily appear to be engaging with "high politics" or traditional routes for peacebuilding. I argue that this multiplicity of practices might be indeed crucial in simultaneously challenging the status-quo and striving to remake citizenship for women faced with a complex and incomplete peace.

\section{Acknowledgments}

I wish to thank Sara Clavero and Giulia Carabelli for their feedback on an earlier draft. I also wish to thank the editorial team and the two anonymous reviewers for their insightful comments and productive suggestions. I am indebted to all the people in Northern Ireland and Bosnia-Herzegovina 
who have inspired and made invaluable contributions to this research piece in many different ways. Any mistakes I have made are my own.

\section{References}

Alison, M. 2009, Women and Political Violence: Female Combatants in Ethno-National Conflict, London: Routledge.

Amnesty International, 2009, Whose Justice? The Women Of Bosnia And Herzegovina Are Still Waiting. Available at http://www.amnesty.org/en/news-and-updates/report/women-raped-duringbosnia-herzegovina-conflict-waiting-justice-20090930 (last accessed 28 November 2012)

Byrne, S. and C. McCulloch, 2012, "Gender, Representation and Power-Sharing in Post-Conflict Institutions" International Peacekeeping, 5(19): 565-580

Carvill, L 2014 "Women in Northern Ireland: Sharing the Learning" Open Democracy, available at https://www.opendemocracy.net/5050/lynn-carvill/women-in-northern-ireland-sharing-learning (last accessed 17 November 2014)

Chikin, C. and K. Paradine, 2001, Vision and Reality: Democracy and Citizenship of Women in the Dayton Peace Accords, The Yale Journal of International Law 26:103-178

Cockburn, C. 2013 "What Became Of 'Frontline Feminism'? A Retro-Perspective On Post-Conflict Belfast", Feminist Review 105: 103-120

Cockburn, C. 2007, From Where We Stand. War, Women's Activism and Feminist Analysis, London: Zed Books

Cohn, C., H. Kinsella, \& S. Gibbings, 2004, "Women, Peace and Security: Resolution 1325", International Feminist Journal of Politics, 6(1):130-140.

Deiana, M.A. 2013b "Women's Citizenship in Northern Ireland after the 1998 Agreement" Irish Political Studies, 28,(3):399-412

Deiana, M.A. 2013a "Citizenship as (Not)Belonging? Contesting the Replication of Gendered and Ethnicised Exclusions in Post-Dayton Bosnia-Herzegovina", 2013 in Roseneil, S. (ed) "Beyond Citizenship? Feminism and the Transformation of Belonging", Bakingstoke: Palgrave McMillan

Deiana, M.A. 2011. "Gender, Citizenship and the Promises of Peace: the Case of BosniaHerzegovina". (Unpublished) PhD thesis. Queen's University Belfast, Belfast.

Dević, A. 2010, "Redefining the Public-Private Boundary: Nationalism and Women's Activism in Former Yugoslavia”, The Anthropology of East Europe Review, Vol.5, pp.45-61.

Enloe, C. 2000, Maneuvers: The International Politics of Militarizing Women's Lives, Berkeley, Los. Angeles and London: University of California Press

Enloe, C. 1989. Bananas, Beaches and Bases. Making Feminist Sense of International Politics, London: University of California Press

Farr, V. 2011 "UNSCR 1325 and Women's Peace Activism in the Occupied Palestinian Territory" International Feminist Journal of Politics, (13)4: 539-556 
Galligan, Y. and K. Knight, 2011. "Attitudes Towards Women In Politics: Gender, Generation And Party Identification In Ireland.” Parliamentary Affairs, 64(4): 585-611

Gray, A. M. and G. Neill, 2011. Creating a shared society in Northern Ireland: why we need to focus on gender equality. Youth and Society, 43(2): 468-487.

Guzina, D. 2007, "Dilemmas of Nation-building and Citizenship in Dayton Bosnia", National Identities, 9(3)217-234

Halsaa, B., S. Roseneil, and S. Sümer, 2012, Remaking Citizenship in Multicultural Europe. Women's Movements, Gender and Diversity, Bakingstoke: Palgrave MacMillan

Helms, E. 2003, "Women as Agents of Ethnic Reconciliation Women's Ngos And International Intervention In Post-War Bosnia-Herzegovina", Women's Studies International Forum, vol26, 15-33

Hinds, B. and D. Donnelly, 2014, Women, Peace and Security: Women's Rights and Gender Equality: Strategic Guide and Toolkit available at http://www.wrda.net/Documents/Toolkit_Booklet.pdf (last accessed 27 January 2015)

Hoewer, M. 2013 "UN Resolution 1325 in Ireland: Limitations and Opportunities of the International Framework on Women, Peace and Security, Irish Political Studies, 28(3): 450-468.

Hughes, J. 2011 “Are Separate Schools Divisive? A Case Study from Northern Ireland” British Educational Research Journal 37(5):829-850

Kandiyoti, D. 1996. "Women, ethnicity and nationalism". In Ethnicity, Edited by: Hutchinson, J. and A. Smith, 311-315. Oxford: Oxford University Press.

Kesić, O. 1999 "Women and Gender Imagery in Bosnia: Amazons, Sluts, Victims, Witches and Wombs" in Ramet, S, Gender Politics in the Western Balkans, Pennsylvania: Pennsylvania State University Press,

Korac, M. (2006), "Gender, Conflict and Peace-building: Lessons from the Conflict in the Former Yugoslavia", Women's Studies International Forum, 29(5):510-520.

Korac, M. (2003) "Women's Organizing against Ethnic Nationalism and War in the Post-Yugoslav States" in Feminist under fire: exchanges across war zones, Giles W. M, Toronto: Between the Lines, $23-33$

Kvinna til Kvinna 2000, Engendering the peace process. A gender approach to Dayton and beyond. Available at: http://kvinnatillkvinna.se/en/files/qbank/55b37c5c270e5d84c793e486d798c01d.pdf (accessed 14 April 2015)

Lister, R., 2003. Citizenship: Feminist Perspectives, 2nd edn, Washington Square, N.Y: New York University Press,

Milić, A. 1993, "Women and nationalism in the Former Yugoslavia" in Gender Politics and PostCommunism, eds. N. Funk \& M. Mueller, Routledge, London, 109-122.

Mladjenovic L. and D. M. Hughes, 1999 "Feminist Resistance to War and Violence in Serbia", avaialable at http://www.uri.edu/artsci/wms/hughes/warvio1.htm (accessed 14 April 2015) 
Mostov, J. 1999 "Sexing the Nation/Desexing the body. Politics of National Identity in the Former Yugoslavia" in Mayer, T. 1999, Gender Ironies of Nationalism, London: Routlegde

McLeod, L. 2011, "Configurations of Post-Conflict: Impacts of Representations of Conflict and PostConflict upon the (Political) Translations of Gender Security within UNSCR 1325" International Feminist Journal of Politics, (13)4:594:611

McWilliams, M. 1995. "Struggling For Peace And Justice: Reflections On Women's Activism In Northern Ireland" Journal of Women's History, 6(4) and 7(1): 13-39.

Myrttinen,H. , J. Naujoks and J. El-Bushra, 2014, Re-thinking Gender in Peace-Building, International Alert, available at http://internationalalert.org/sites/default/files/Gender_RethinkingGenderPeacebuilding_EN_2014.pdf (last accessed 17 November 2014)

O’Dowd, K 2014, “Peace Will Bring Prosperity: Northern Ireland's Big Lie?” Open Democracy, available at https://www.opendemocracy.net/5050/kellie-odowd/\%E2\%80\%98peace-will-bringprosperity $\% \mathrm{E} 2 \% 80 \% 99$-northern-ireland $\% \mathrm{E} 2 \% 80 \% 99$ s-big-lie (last accessed 17 November 2014)

Potter, M. 2014, “Loyalism, Women and Standpoint Theory”, Irish Political Studies, 29(2): 258-274.

Pratt N. and S. Richter-Devroe 2011, "Critically Examining UNSCR on Women, Peace and Security, ", International Feminist Journal of Politics, (13)4:489-503

Raccioppi, L. and K. O'Sullivan, 2006. "Engendering Democratic Transition from Conflict: Women's Inclusion in Northern Ireland's Peace Process." Comparative Politics, 38(2): 189-208

Roseneil, S. (ed), 2013. Beyond Citizenship? Feminism and the Transformation of Belonging, Basingstoke: Palgrave MacMillan

Sawyer, R. 1993. We Are But Women: Women in Ireland's History, London: Routledge

Sarajlić, E. 2012 "Conceptualising Citizenship Regime(s) in Post-Dayton Bosnia and Herzegovina" Citizenship Studies, 16:3:367-381

Shepherd, L. J. 2011 "Sex, Security and Superhero(in)es: From 1325 to 1820 and Beyond", International Feminist Journal of Politics, (13)4:504-521

Slapšak, S. 1997 "Nationalist and Women's discourse in Post-Yugoslavia” in J. Scott, C. Kaplan, D. Keates, Transitions, Environments, Translations. Feminisms in International Politics. New York: Routledge.

Tryggestad, T. L. 2009. Trick or treat? The UN and implementation of Security Council 1325 on Women, Peace and Security. Global Governance, (15):539-557

Ward, M, 2013 "Excluded and Silenced. Women in Northern Ireland after the Peace Process Open Democracy, available at https://www.opendemocracy.net/5050/margaret-ward/excluded-andsilenced-women-in-northern-ireland-after-peace-process (last accessed 17 November 2014)

Ward, M. 2005. "Gender, Citizenship and The Future Of The Northern Ireland Peace Process". EireIreland, 40(3 \& 4): 1-22. 
Women's International League for Peace and Freedom, 2013, Open Letter to International Community in Bosnia \& Herzegovina, available at http:/www.wilpfinternational.org/open-letter-tointernational-community-in-bosnia-herzegovina/ (last accessed 18 November 2014)

Women's Resource and Development Agency. 2008. Women and the Conflict Report. Talking about the 'Troubles' and Planning for the Future, available at: http://www.wrda.net/Documents/Women_\&_ConflictReport.pdf (last accessed 17 November 2014)

Wilford, R. 2010. Northern Ireland: the politics of constraint. Parliamentary Affairs, 63(1): 134-155

Yuval-Davis, N. 1999. The 'Multi-layered Citizen': Multi-layered Citizenship in the Age of 'Globalization'. International Feminist Journal of Politics, 1(1): 119-137.

Yuval-Davis, N. 1997. Gender and Nation, London and Thousand Oaks, CA: Sage Publications.

Žarcov, D. 2007 The Body of War. Media Ethnicity and Gender in the Break-Up of Yugoslavia. Durham, N.C.: Duke University Press

Žene Ženama, 2011 Implementation of UNSCR 1325: Integration of Gender Sensitive Policies in the Security Sector in Bosnia-Herzegovina. Available at http://www.peacewomen.org/assets/file/bosnia_cso_review_nsp_ssr.pdf (accessed 14 April 2015)

Žene Ženama, 2007, Monitoring and Impementation of UN SCR 1325 in Bosnia and Herzegovina. Final Report. Sarajevo. Available at http://www.peacewomen.org/sites/default/files/1325_finalreportmonimp1325inbih_zenezenamasaraje vo 2007.pdf (accessed 14 April 2015)

\footnotetext{
${ }^{\mathrm{i}}$ This body of work is reflective of the somewhat monumental aspirations in the agenda of mainstreaming gender in all aspects of conflict transformation and peacebuilding. See for example Myrttinen, Naujoks and El-Bushra, 2014, Hower, 2013; Pratt and Richter-Devroe, 2011; Tryggestad, 2009, Cockburn, 2007; Cohn, Kinsella, and Gibbings, 2004)

ii Another reason for shifting the focus from the top-down dimension of implementation lies in the fact that NI remains a blind spot within the UNSCR1325 agenda. Despite the UK official commitment to a National Action Plan, the British Government does not acknowledge "the Troubles" as a case of armed conflict, thus leaving NI out of their 1325 remit. The Irish Government has included references to NI in its NAP .However the history of competing nationalisms raises sensitivities around implementation (see Hoewer, 2013). $\mathrm{BiH}$, on the other hand, currently has a NAP for UNSCR1325, but I contend that this rhetorical commitment clashes with the entrenchment of ethno-national rhetoric. These problems do not make 1325 completely redundant because, as I will argue, activists in Northern Ireland and Bosnia- Herzegovina draw on the vision and principles of UNSCR1325 to craft their demands for inclusion. Nevertheless, these dynamics are illustrative of the need to critically interrogate the applicability of UNSCR1325 to different scenarios.
} 
iii This study draws on interviews and ethnographic data which I have gathered in Bosnia-Herzegovina and Northern Ireland in 2010-2014. In BiH I conducted 25 in-depth interviews with feminists, civil society activists, members of political parties, officials in (local and international) gender machinery institutions, academics, individuals working in cultural production and the media. Other methods included participant observation at cultural events, meetings and conferences organised by activists in Sarajevo, Mostar and Banja Luka. I analysed this data together with cultural products, installations and media clipping in my doctoral thesis "Gender, Citizenship and the Promises of Peace: the Case of Post-Dayton Bosnia-Herzegovina" (Deiana 2011). Data collection in Northern Ireland involved participant observation at the following consultation processes: Round Table "Conflict Prevention and Peacebuilding", Women Delivering Peace \& Security- Hanna's House All Ireland Conference, Croke Park, Dublin, 05 November 2012; “Haas-O’Sullivan Taks: What do Women Think? - Europa Hotel Belfast, 01 March 2014; Consultative Workshop on the Development of Ireland's second National Action Plan on Women, Peace and Security- Conflict Resolution Unit, Department of Foreign Affairs and Trade, Iveagh House, Dublin 2 October 2014. Since June 2012 I have been involved in Belfast Feminist Network both as a researcher (see Deiana, 2013b) and as an active member. In 2013 I co-facilitated a series of meetings exploring the experiences of women living in interface areas within the project "Fostering Dialogue Across Divides" led by Mediation Northern Ireland in cooperation with BFN. Insights from the project also inform this study. Finally, information analysed here derives from personal conversations with activists in $\mathrm{BiH}$ and $\mathrm{NI}$ and from social media analysis.

iv Unionism and Nationalism identify the two main opposing political formations in NI while, respectively, loyalism and republicanism refer to their more overtly militant forms.

$\checkmark$ The parties in power could not find a shared strategy for the issuing of ID cards as a result of ethnic differences/vetoes.

vi The two terms are not synonyms: while power-sharing is a central feature of consociationalism, together with weighted voting, group autonomy and proportionality, this can be used in its broadest sense to identify "various forms of non-majoritarian governance" (Byrne and McCulloch, 2012 :568).

vii This cohesive effort was reinforced by a pragmatic approach that focused on promoting the existing structures of the Good Friday Agreement as a framework for the implementation of 1325 and, thus also circumvented opposing visions of the state held by different women's groups (see for example, Hinds and Donnelly, 2014). At the same time, the potential of this approach is also constrained by the gendered and ethnicised order institutionalised by power-sharing. Whether this space can be opened up through grassroots mobilization and links with the public sector and political stakeholders remains an open question (see However, 2013).

viii See Facebook pages https://www.facebook.com/ReclaimTheAgendaNI , https://www.facebook.com/BelfastFeministNetwork and https://belfastfeminist.wordpress.com/

ix See Facebook page https://www.facebook.com/crvena.ba and https://www.facebook.com/pages/FondacijaCureCURE-Foundation/282491238469337?fref=ts 